\title{
ANALYSIS OF WARNING LETTER AND DISTRESS WARRANT AGAINST THE DISBURSEMENT OF TAX ARREARS AT THE NORTH JAKARTA MIDDLE TAX OFFICE
}

1Universitas Bina Sarana Informatika, Fakultas Ekonomi dan Bisnis, Prodi Manajemen Pajak
dinar.drf@bsi.ac.id
2Sugiarti, Fakultas Ekonomi dan Bisnis, Prodi Administrasi Bisnis
sugiarti.ugt@bsi.ac.id

\section{PENDAHULUAN}

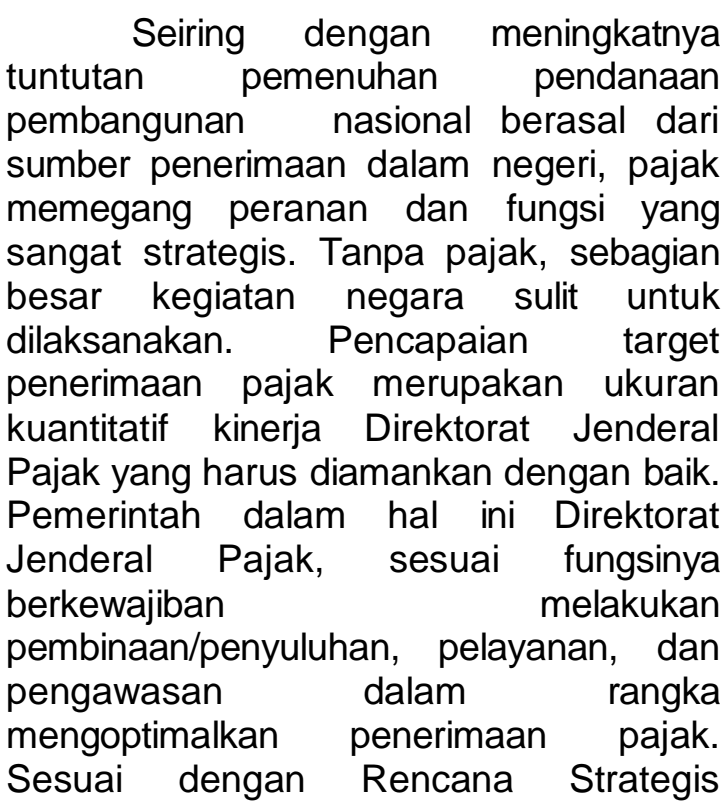

Direktorat Jenderal Pajak tahun 2015 2019, tujuan yang dicapai adalah optimalisasi penerimaan negara. (Wahdi, Ratna, \& Danang, 2018)

Peningkatan penerimaan pajak yang semakin meningkat dari tahun ke tahun diiringi juga dengan semakin besar tunggakan pajak. Salah satu faktor besarnya tunggakan pajak ini disebabkan karena tingkat kesadaran dan kepatuhan wajib pajak (WP) Pribadi dan Badan dalam memenuhi kewajiban pajaknya masih sangat rendah. Rendahnya kesadaran wajib pajak dalam membayar kewajiban pajaknya, ternyata proses penagihan dan pencairan tunggakan pajak yang dilakukan Dirjen Pajak masih kurang efektif. (Fitrisyah \& Ermadiani, 2014) 
Berdasarkan UU Nomor 19 Tahun 1997 tentang Penagihan Pajak dengan Surat Paksa (UU PPSP) dan kemudian diubah dengan UU Nomor 19 Tahun 2000 , terdapat beberapa cara yang dapat dilakukan oleh Dirjen pajak dalam penagihan tunggakan pajak seperti: pemberitahuan surat teguran, surat paksa, penagihan seketika dan sekaligus, melaksanakan penyitaan, melaksanakan penyanderaan, serta menjual barang yang telah disita dari wajib pajak. (Fitrisyah \& Ermadiani, 2014).

Berdasarkan uraian latar belakang diatas maka rumusan masalah dalam penelitian ini adalah:

1. Apakah terdapat hubungan yang signifikan secara parsial dan simultan antara Surat Teguran dan Surat Paksa terhadap Pencairan Tunggakan Pajak Pada KPP Madya Jakarta Utara?

2. Apakah terdapat pengaruh yang signifikan secara simultan antara Surat Teguran dan Surat Paksa terhadap Pencairan Tunggakan Pajak Pada KPP Madya Jakarta Utara?

3. Apakah persamaan regresi berganda yang terbentuk antara Surat Teguran dan Surat Paksa terhadap Pencairan Tunggakan Pajak Pada KPP Madya Jakarta Utara signifikan?

\section{KERANGKA TEORITIS DAN PENGEMBANGAN HIPOTESIS}

\section{Pengertian Pajak}

Menurut

("Undang-Undang

Republik Indonesia Nomor 28 Tahun 2007 Tentang Perubahan Ketiga Atas Undang-Undang Nomor 6 Tahun 1983 Tentang Ketentuan Umum Dan Tata Cara Perpajakan," 2007) pajak adalah kontribusi waib kepada negara yang terutang oleh orang pribadi atau badan yang bersifat memaksa berdasarkan Undang-undang, dengan tidak mendapatkan imbalan secara langsung dan digunakan untuk keperluan negara bagi sebesar-besarnya kemakmuran rakyat.

\section{Wajib Pajak Patuh}

Wajib pajak menurut (Hidayat, 2013) dapat dikatagerokan sebagai wajib pajak patuh apabila memenuhi syarat berikut:

- Tepat waktu dalam menyampaikan SPT untuk semua jenis pajak dalam 2 tahun terakhir.

- Tidak mempunyai tunggakan pajak untuk semua jenis pajak, kecuali telah memperoleh izin mengangsung atau menunda pembayaran pajak.

- Tidak pernah dijatuhi hukuman karena melakukan tindak pidana dibidang perpajakan dalam jangka waktu 10 tahun terakhir.

- Dalam hal laporan keuangan diaudit oleh akuntan publik atau Badan Pengawasan Keuangan dan Pembangunan harus dengan pendapat wajar tanpa pengecualian atau dengan pendapat wajar dengan pengecualian sepanjang pengecualian tersebut tidak mempengaruhi laba rugi fiskal.

\section{Hambatan Pemungutan Pajak}

Dalam pemungutan pajak, menurut (Ratnawati \& Retno, 2015) terdapat beberapa hambatan pemungutan pajak yang dapat dikelompokkan menjadi:

\section{Perlawanan pasif}

Masyarakat Wajib Pajak mulai enggan membayar pajak, biasanya disebabkan oleh:

a. Perkembangan intelektual dan moral

b. Sistem perpajakan yang sulit dipahami

c. Sistem kontrol yang tidak dapat dilaksanakan dengan baik

2. Perlawanan aktif 
Semua tindakan yang secara langsung ditujukan kepada para petugas pajak untuk menghindari mambayar pajak.

a. Tax Avoidance, yaitu usaha meringankan beban pajak dengan cara tidak melanggar undangundang. Contoh tidak membeli produk jika tidak ingin dikenakan PPN.

b. Tax Evasio, yakni usaha meringankan beban pajak dengan cara melanggar undang-undang. Contoh manipulasi laporan keuangan.

\section{Penagihan Pajak}

Menurut (Ayza, 2017) Penagihan pajak adalah serangkaian tindakan agar penanggung pajak melunasi utang pajak dan biaya penagihan pajak. Tindakan penagihan dimaksud meliputi menegur atau memperingatkan, melaksanakan Penagihan Pajak Seketika dan Sekaligus (PPSP), memberitahukan Surat Paksa (SP), mengusulkan pencegahan, melaksanakan penyitaan, dan menjual barang yang telah disita dan/atau melaksanakan penyanderaan.

Penagihan pajak dapat dilakukan secara pasif maupun aktif. Penagihan pasif belum bersifat meminta pembayaran. Contoh penagihan pasif adalah surat peringatan dan surat teguran. Penagihan aktif bersifat memaksa untuk melunasi pajak yang tidak dibayar. Penagihan ini bersifat paksaan yang bersifat langsung. Termasuk dalam penagihan ini adalah surat tagihan pajak, surat ketetapan pajak, dan surat paksa. Tindakan penagihan melalui surat paksa merupakan bentuk eksekusi langsung, yaitu eksekusi tanpa keputusan hakim. Jika setelah dikeluarkan surat paksa, utang pajak masih belum dilunasi, maka dilakukan tindakan penyitaan atau penyanderaan. (Soemarso, 2007)

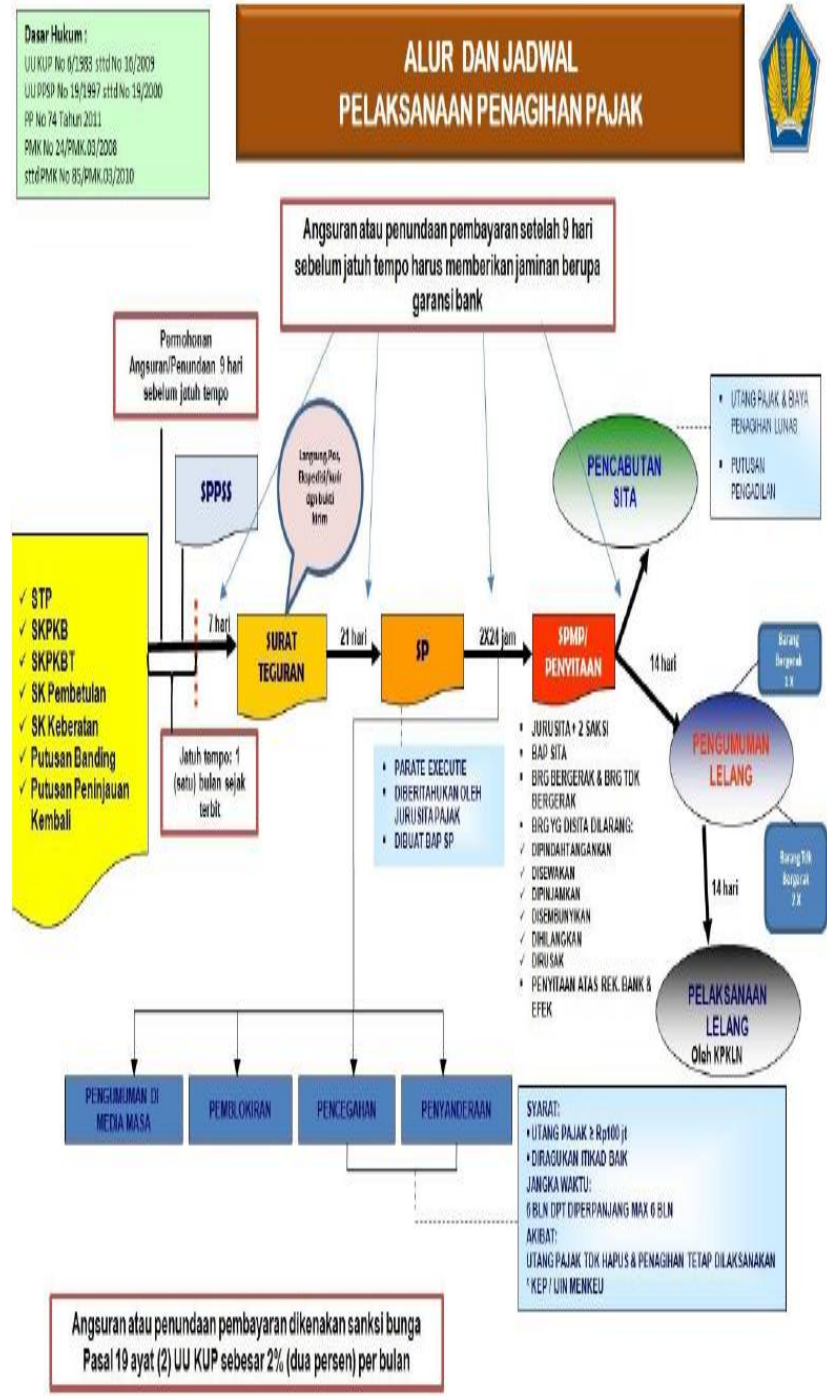

Sumber KPP Madya Jakarta Utara

\section{Gambar 1 Alur dan Jadwal Pelaksanaan Penagihan Pajak}

\section{Surat Teguran}

Surat teguran, surat peringatan atau surat lain yang sejenis adalah surat yang diterbitkan oleh pejabat untuk menegur atau memperingatkan kepada WP untuk melunasi utang pajaknya atau penanggung pajak tidak melunasi utang pajaknya sampai dengan tanggal jatuh tepo pembayaran. Jadwal waktu pelaksanaan surat teguran adalah setalah lewat 7 (tujuh) hari dari jatuh tempo pembayaran Surat ketetapan Pajak (SKP). (Lubis, 2011)

Surat teguran ini diterbitkan apabila utang pajak yang tercantum 
berdasarkan Surat Tagihan Pajak (STP), Surat Ketetapan Pajak Kurang Bayar (SKPKB) dan Surat Ketetapan Pajak Kurang Bayar Tambahan (SKPKBT) sampai melewati waktu 7 (tujuh) hari dari batas waktu jatuh tempo 1 bulan sejak tanggal diterbitkannya. (Fitrisyah \& Ermadiani, 2014)

\section{Surat Paksa}

Berdasarkan UU Republik Indonesia Nomor 19 Tahun 2007 Tentang Penagihan Pajak dengan Surat Paksa, Surat Paksa adalah surat perintah membayar utang pajak dan biaya penagihan pajak. (Nasution \& Aliffoni, 2018)

Surat paksa diterbitkan apabila:

a. Penanggung pajak tidak melunasi utang pajak dan kepadanya telah diterbitkan surat teguran atau surat peringatan atau surat lain yang sejenis;

b. Terhadap penanggung pajak telah dilaksanakan penagihan seketika dan sekaligus; atau

c. Penanggung pajak tidak memenuhi ketentuan sebagaimana tercantum dalam keputusan persetuuan angsuran atau penundaan pembayaran pajak.

Pada dasarnya surat paksa diterbitkan setelah surat teguran, atau surat peringatan, atau surat lain yang sejenis diterbitkan oleh pejabat. Dalam hal penagihan seketika dan sekaligus surat paksa diterbitkan oleh pejabat baik sebelum maupun sesudah penerbitan surat teguran, atau surat peringatan, atau surat lain yang sejenis. (Lubis, 2011)

Menurut Pohan dalam (Sabrina, Siska, \& Kurnia, 2018) prosedur penagihan dengan Surat Paksa menjelaskan sifat Surat Paksa, yaitu berkekuatan hukum yang sama dengan putusan Hakim dalam perkara perdata yang tidak dapat diminta banding lagi pada Hakim atasan, berkekuatan hukum yang pasti, dan mempunyai fungsi ganda yaitu menagih pajak dan menagih bukan pajak (biaya-biaya penagihan).

\section{Pencairan Tunggakan Pajak}

Menurut UU KUP dalam (Sabrina, Siska, \& Kurnia, 2018) pencairan tunggakan pajak adalah pembayaran yang dilakukan dengan menggunakan surat setoran pajak, yang digunakan untuk pelunasan piutang pajak.

Perkembangan jumlah tunggakan pajak dari waktu ke waktu menunjukkan jumlah yang semakin besar dan masih belum dapat diimbangi dengan kegiatan pencairan terhadap tunggakan pajak dimaksud melalui tindakan penagihan pajak yang mempunyai kekuatan hukum yang memaksa. Kepatuhan wajib pajak dalam membayar pajak merupakan posisi strategis dalam peningkatan penerimaan pajak. (M.Farouq.S, 2018)

Menurut Waluyo dalam (Fatmadika, Heru, \& Rosalita, 2016) Pajak yang telah dilunasi termasuk sanksi administrasi dalam masa tagihan pajak. Pencairan tunggakan pajak ini harus dibayar dengan surat setoran pajak, yang digunakan untuk membayar pelunasan utang pajak Penanggung Pajak untuk menambah penerimaan negara.

\section{Koefisien Korelasi}

Menurut (Syofian Siregar, 2017) Koefisien korelasi adalah bilangan yang menyatakan kekuatan hubungan antara dua variabel atau lebih atau juga dapat menentukan arah dari kedua variabel.

Nilai Korelasi $(r)=(-1 \leq 0 \leq 1)$.

Untuk kekuatan hubungan, nilai koefisien korelasi berada diantara -1 dan 1, sedangkan untuk arah dinyatakan dalam bentuk positif $(+)$ dan negative (-).

a. Apabila $r=-1$, artinya korelasi negatif sempurna, artinya terjadi hubungan bertolak belakang antara variabel $X$ dan variabel $Y$, bila variabel $X$ naik, maka variabel $Y$ turun.

b. Apabila $r=1$, artinya korelasi positif sempurna, artinya terjadi hubungan 
searah variabel $X$ dan variabel $Y$, bila variabel $X$ naik, maka variabel $Y$ naik.

Tabel 1

Tingkat Korelasi dan Kekuatan Hubungan

\begin{tabular}{|c|l|l|}
\hline NO & $\begin{array}{c}\text { Nilai } \\
\text { Korelasi }(\mathbf{r})\end{array}$ & \multicolumn{1}{|c|}{$\begin{array}{c}\text { Tingkat } \\
\text { Hubungan }\end{array}$} \\
\hline 1 & $0,00-0,199$ & Sangat Lemah \\
\hline 2 & $0,20-0,399$ & Lemah \\
\hline 3 & $0,40-0,599$ & Cukup \\
\hline 4 & $0,60-0,799$ & Kuat \\
\hline 5 & $0,80-0,100$ & Sangat Kuat \\
\hline
\end{tabular}

Sumber: (Syofian Siregar, 2017)

\section{Koefisien Determinasi}

Koefisien determinasi $\left(r^{2}\right)$ adalah sebuah bilangan yang menyebutkan proporsi (presentase) variasi perubahan nilai-nilai $Y$ yang ditentukan oleh variasi perubahan nilai-nilai X. (Gani \& Siti, 2015)

Koefisien determinasi dilambangkan dengan $r^{2}$. Nilai ini menyatakan proporsi variasi keseluruhan dalam nilai variabel dependent yang dapat diterangkan atau diakibatkan oleh hubungan linear dengan variabel independent, selain itu (sisanya) diterangkan oleh variabel yang lain (galat atau peubah nilainya). Nilai koefisien determinasi dinyatakan dalam kuadrat dari nilai koefisien korelasi $r^{2} \times 100 \%=$ $\mathrm{n} \%$, memiliki makna bahwa nilai variabel dependent dapat diterangkan oleh variabel independent sebesar $\mathrm{n} \%$, sedangkan sisanya sebesar (100-n)\% diterangkan oleh galat (error) atau pengaruh variabel yang lain. (Supardi, 2013)

Koefisien Determinasi dirumuskan:

$$
\begin{aligned}
\mathrm{KD} & =r^{2} \times 100 \% \\
\mathrm{KD} & =\text { Koefisien Determinasi } \\
r \quad & =\text { Koefisien Korelasi }
\end{aligned}
$$

\section{Koefisien Regresi Linear Berganda}

Penerapan metode regresi
berganda jumlah variabel bebas

(independent) yang digunakan lebih dari satu yang mempengaruhi satu variabel tak bebas (dependent). menurut (Syofian Siregar, 2017). Rumus regresi linear berganda:

$Y=a+b_{1} X_{1}+b_{2} X_{2}+b_{3} X_{3} \ldots+b_{n} X_{n}$

Dimana:

$\mathrm{Y}=$ Variabel terikat, $\mathrm{X}_{1}=$ Variabel bebas pertama, $\mathrm{X}_{2}=$ Variabel bebas kedua

$\mathrm{X}_{3}=$ Variabel bebas ketiga, $\mathrm{X}_{\mathrm{n}}=$ Variabel bebas ke...n a dan $b_{1}$ serta $b 2=$ Konstanta

\section{Penelitian Terdahulu}

Penelitian terdahulu oleh Rantasari, Nur dan M Cholid Mawardi tahun 2019 secara simultan penagihan dengan surat Teguran dan Surat Paksa tidak berpengaruh terhadap peningkatan penerimaan pajak. Penelitian yang dilakukan oleh Fitrisyah dan Ermadiani tahun 2014 berdasarkan uji hipotesis terhadap variabel surat teguran dan surat paksa bahwa baik jumlah surat teguran maupun jumlah surat paksa yang diterbitkan untuk wajib pajak badan tidak berpengaruh signifikan terhadap penerimaan tunggakan pajak badan pada KPP Pratama Palembang Seberang Ulu.

Hasil penelitian Wungkar dan Elim tahun 2016 penerbitan Surat Paksa sebagai upaya penagihan aktif dan kontribusinya terhadap pencairan tunggakan pajak pada KPP Pratama Kotamobagu tidak efektif. Penelitian yang sama dijelaskan oleh Juniardi et al tahun 2014, secara parsial penagihan aktif memiliki pengaruh tidak signifikan terhadap jumlah pencairan tunggakan pajak dalam (Sabrina, Siska, \& Kurnia, 2018).

Saputri tahun 2013 pengaruh penagihan pajak dengan surat teguran dan surat paksa terhadap efektivitas 
pencairan tunggakan pajak di KPP

Pratama Bandung membuktikan mempunyai pengaruh yang signifikan terhadap pencairan tunggakan pajak. Ritonga tahun 2012 pengaruh tindakan penagihan aktif terhadap pencairan tunggakan pajak Di Kantor Pelayanan Pajak Pratama Manado mempunyai pengaruh yang signifikan. Marduati tahun 2012 penelitian pengaruh penagihan pajak dengan Surat Paksa terhadap pencairan tunggakan pajak di Kantor Pelayanan Pajak Pratama Makasar Barat menunjukkan dari jumlah Surat Teguran dan Surat Paksa yang diterbitkan serta jumlah wajib pajak aktif, baik secara simultan maupun parsial berpengaruh signifikan terhadap pencairan tunggakan pajak di Kantor Pelayanan Pajak Pratama Makasar Barat. Dalam (Rantasari, Nur, \& M. Cholid Mawardi, 2019)

\section{Kerangka Konseptual}

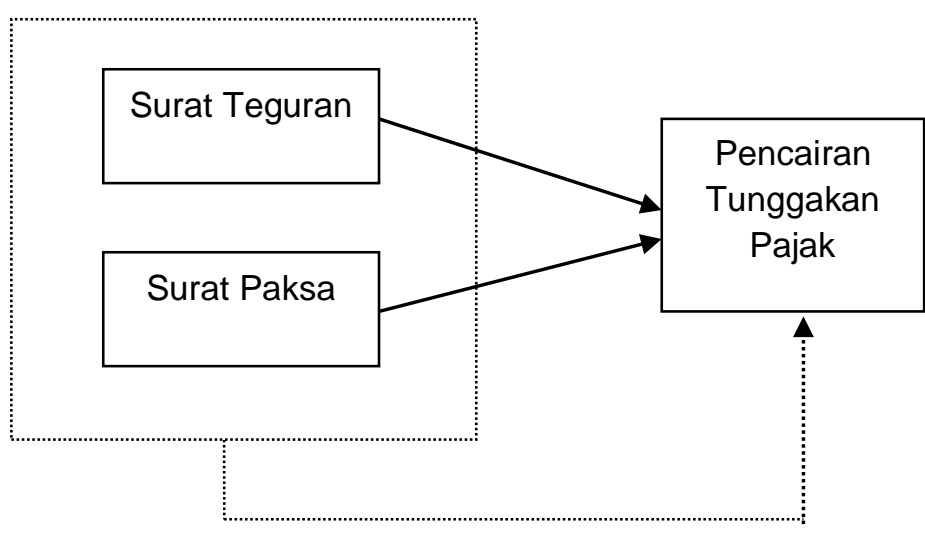

\section{Gambar 2 Kerangka Konseptual}

\section{Hipotesis Penelitian}

Berdasarkan gambar 2 kerangka konseptual diatas, maka hipotesis penelitian sebagai berikut:

$\mathrm{Ha}_{1}$ : Terdapat hubungan yang signifikan secara parsial antara Surat Teguran terhadap Pencairan Tunggakan Pajak.

$\mathrm{Ha}_{2}$ : Terdapat hubungan yang signifikan secara parsial antara Surat Paksa terhadap Pencairan Tunggakan Pajak.

$\mathrm{Ha}_{3}$ : Terdapat hubungan yang signifikan antara Surat Teguran dan Surat Paksa terhadap Pencairan Tunggakan Pajak.
$\mathrm{Ha}_{4}$ : Terdapat pengaruh yang sinifikan antara Surat Teguran dan Surat Paksa terhadap Pencairan Tunggakan Pajak.

$\mathrm{Ha}_{5:}$ Persamaan regresi yang terbentuk signifikan antara Surat Teguran dan Surat Paksa terhadap Pencairan Tunggakan Pajak.

\section{METODOLOGI PENELITIAN}

Penelitian ini dilakukan pada Kantor Pelayanan Pajak Madya Jakarta Utara. Penelitian ini menggunakan pendekatan metode kuantitatif dimana data yang digunakan dalam penelitian ini berbentuk angka. Teknik pengumpulan Data dalam penelitian menggunakan data sekunder berupa jumlah penerbitan Surat Teguran dan Surat Paksa serta Penerimaan Pencairan Tunggakan Pajak setelah diterbitkannya Surat Teguran dan Surat Paksa periode tahun 2013 sampai dengan 2017.

Teknik analisis data yang digunakan adalah pengujian koefisien korelasi, uji koefisien determinasi, dan regresi linier berganda.

\section{HASIL DAN PEMBAHASAN}

\section{Uji Koefisien Korelasi}

Berikut merupakan hasil output IBM SPSS 21 dan pengambilan keputusan serta kesimpulan mengenai hubungan secara parsial dan simultan antara variabel bebas $\left(X_{1}\right.$ dan $\left.X_{2}\right)$ terhadap variabel terikat $(\mathrm{Y})$ :

1. Uji koefisien korelasi secara parsial antara Surat Teguran $\left(X_{1}\right)$ terhadap Pencairan Tunggakan Pajak (Y), apabila Surat Paksa $\left(X_{2}\right)$ sebagai pengendali (dibuat konstan).

Hipotesis:

$\mathrm{Ho}_{1}$ : Tidak terdapat hubungan yang signifikan secara parsial antara Surat Teguran terhadap Pencairan Tunggakan Pajak.

$\mathrm{Ha}_{1}$ : Terdapat hubungan yang signifikan secara parsial antara Surat Teguran terhadap Pencairan Tunggakan Pajak.

Pengambilan keputusan: 
Jika Sig $<\alpha$, maka Ho ditolak.

Jika Sig $>\alpha$, maka Ho diterima.

\section{Tabel 2}

Correlations

\begin{tabular}{|c|c|c|c|c|}
\hline & & surattequan & syrat palsa & $\begin{array}{c}\text { pencaican } \\
\text { tunogakan pajek }\end{array}$ \\
\hline \multirow{4}{*}{ Sylditteguran } & Pearson Correlation & 1 & .052 & .102 \\
\hline & Sig.(2-alaled) & & 693 & 439 \\
\hline & N & 60 & 60 & 60 \\
\hline & Pearson Correlation & .052 & 1 & . 153 \\
\hline \multirow[t]{3}{*}{ Syratalaksa } & Sig.(2-alaled) & .693 & & .244 \\
\hline & N & 60 & 60 & 60 \\
\hline & Pearson Correlation & .102 & .153 & 1 \\
\hline \multirow[t]{2}{*}{ pencairantunogakan pajak } & Sig,(2-ataled) & .439 & .244 & \\
\hline & N & 60 & 60 & 60 \\
\hline
\end{tabular}

Sumber: Data diolah menggunakan IBM SPSS 21

Berdasarkan tabel 2 correlation diatas didapat nilai signifikan untuk variabel Surat Teguran $\left(\mathrm{X}_{1}\right)$ sebesar $0.439>0.05$ sehingga Ho diterima yang artinya tidak terdapat hubungan secara parsial antara Surat Teguran terhadap Pencairan Tunggakan Pajak.

2. Uji koefisien korelasi secara parsial antara Surat Paksa $\left(X_{2}\right)$ terhadap Pencairan Tunggakan Pajak (Y), apabila surat teguran $\left(X_{1}\right)$ sebagai pengendali (dibuat konstan).

Hipotesis :

$\mathrm{Ho}_{2}$ : Tidak terdapat hubungan yang signifikan secara parsial antara Surat Paksa terhadap Pencairan Tunggakan Pajak.

$\mathrm{Ha}_{2}$ : Terdapat hubungan yang signifikan secara parsial antara Surat Paksa terhadap Pencairan Tunggakan Pajak.

Berdasarkan tabel 2 correlation diatas didapat nilai signifikansi untuk variabel Surat Paksa $\left(X_{2}\right)$ terhadap Total Pencairan Tunggakan Pajak sebesar $0.244>0.05$ sehingga Ho diterima yang artinya tidak terdapat hubungan secara parsial antara Surat Paksa terhadap Pencairan Tunggakan Pajak.

3. Uji koefisien korelasi secara simultan antara Surat Teguran $\left(\mathrm{X}_{1}\right)$ dan Surat
Paksa $\left(X_{2}\right)$ terhadap Pencairan Tunggakan Pajak ( $\mathrm{Y}$ )

Hipotesis :

$\mathrm{Ho}_{3}$ : Tidak terdapat hubungan yang signifikan secara simultan antara Surat Teguran dan Surat Paksa terhadap Pencairan Tunggakan Pajak.

$\mathrm{Ha}_{3}$ : Terdapat hubungan yang signifikan secara secara simultan antara Surat Teguran dan Surat Paksa terhadap Pencairan Tunggakan Pajak.

\section{Tabel 3}

Model Summary

\begin{tabular}{|c|c|c|c|c|c|c|c|c|c|}
\hline \multirow[t]{2}{*}{ Model } & \multirow[t]{2}{*}{$R$} & \multirow{2}{*}{$\begin{array}{c}R \\
\text { Square }\end{array}$} & \multirow{2}{*}{$\begin{array}{c}\text { Adjusted R } \\
\text { Square }\end{array}$} & \multirow{2}{*}{$\begin{array}{l}\text { Std. Error of } \\
\text { the Estimate }\end{array}$} & \multicolumn{5}{|c|}{ Change Statistics } \\
\hline & & & & & $\begin{array}{l}\text { RSquare } \\
\text { Change }\end{array}$ & $\begin{array}{c}\mathrm{F} \\
\text { Change } \\
\end{array}$ & $d f 1$ & $d f^{2}$ & $\begin{array}{l}\text { Sig.F } \\
\text { Change } \\
\end{array}$ \\
\hline 1 & $.179^{\circ}$ & .032 & .002 & $\begin{array}{r}12,940,009,6 \\
99,969\end{array}$ & .032 & .947 & 2 & 57 & 394 \\
\hline
\end{tabular}

a. Predictors: (Constant), surat paksa, surattequjan

Sumber: Data diolah menggunakan IBM SPSS 21 Berdasarkan tabel 3 Model Summary diatas, nilai Sig. $\mathrm{F}_{\text {Change yang }}$ diperoleh sebesar $0.394>0.05$, maka Ho diterima yang artinya tidak terdapat hubungan secara simultan antara Surat Teguran dan Surat Paksa terhadap Pencairan Tunggakan Pajak.

Hasil Penelitian menunjukkan bahwa surat teguran dan surat paksa tidak dapat meningkatkan kepatuhan wajib pajak dalam melaksanakan hak dan kewajiban perpajakan sebagai upaya meningkatkan pencairan tunggakan pajak yang dilakukaan oleh Kantor Pelayanan Pajak Pratama Madya Jakarta Utara sehingga pencairan tunggakan pajak belum dapat meningkatkan penerimaan pajak kedalam kas negara.

\section{Uji Koefisien Determinasi}

Berikut merupakan hasil output IBM SPSS 21 dan pengambilan keputusan serta kesimpulan mengenai koefisien determinasi secara simultan antara variabel bebas $\left(X_{1}, X_{2}\right)$ terhadap variabel terikat $(\mathrm{Y})$ :

Hipotesis:

$\mathrm{Ho}_{4}$ : Tidak terdapat pengaruh yang signifikan secara simultan antara Surat Teguran dan Surat Paksa terhadap Pencairan Tunggakan Pajak. 
$\mathrm{Ha}_{4}$ : Terdapat pengaruh yang signifikan secara simultan antara Surat Teguran dan Surat Paksa terhadap Pencairan Tunggakan Pajak.

Pengambilan keputusan :

Jika $\mathrm{F}_{\text {Hitung }}<\mathrm{F}_{\text {Tabel, }}$, maka $\mathrm{Ho}_{4}$ diterima.

Jika $\mathrm{F}_{\text {Hitung }}>\mathrm{F}_{\text {Tabel, }}$ maka $\mathrm{Ho}_{4}$ ditolak.

$\alpha=5 \%=0,05$

$\mathrm{F}_{\text {Tabel }}=\mathrm{F}_{(\alpha, \mathrm{k} ; \mathrm{dk})}=\mathrm{F}_{(0,05,2 ; 60-2-1)}=\mathrm{F}$ $(0,05),(2 ; 57)=3.16$

\section{Tabel 4}

Model Sunmary

\begin{tabular}{|c|c|c|c|c|c|c|c|c|c|}
\hline \multirow{2}{*}{ Mod } & \multirow[t]{2}{*}{$R$} & \multirow{2}{*}{$\begin{array}{c}R \\
\text { Square }\end{array}$} & \multirow{2}{*}{$\begin{array}{l}\text { Adjusted R } \\
\text { Square }\end{array}$} & \multirow{2}{*}{ Sto. Error of } & \multicolumn{5}{|c|}{ Change Statistics } \\
\hline & & & & & $\begin{array}{l}\text { RSquare } \\
\text { Change }\end{array}$ & $\begin{array}{c}F \\
\text { Change }\end{array}$ & dif & dit? & $\begin{array}{l}\text { Sig.F } \\
\text { Change }\end{array}$ \\
\hline 1 & $.178^{\mathrm{s}}$ & .032 & .002 & $\begin{array}{r}12,940,009, \\
699.969\end{array}$ & .032 & .947 & 2 & 57 & 394 \\
\hline
\end{tabular}

a. Predictos: (Constart), surat paksa, surat tequran

Sumber: Data diolah menggunakan IBM SPSS 21

Berdasarkan tabel Model Summary diatas, nilai $F_{\text {Change yang }}$ diperoleh sebesar $0.947<3.16$, maka Ho diterima yang artinya tidak terdapat Pengaruh secara simultan antara Surat Teguran dan Surat Paksa terhadap Pencairan Tunggakan Pajak.

\section{Uji Persamaan Regresi}

Berikut merupakan hasil output IBM SPSS 21 dan pengambilan keputusan serta kesimpulan mengenai koefisien determinasi secara simultan antara variabel bebas $\left(X_{1}, X_{2}\right)$ terhadap variabel terikat $(\mathrm{Y})$ :

Hipotesis:

$\mathrm{Ho}_{5}$ : Persamaan regresi yang terbentuk tidak signifikan antara Surat Teguran dan Surat Paksa terhadap Pencairan Tunggakan Pajak.

$\mathrm{Ha}_{5}$ : Persamaan regresi yang terbentuk signifikan antara Surat Teguran dan Surat Paksa terhadap Pencairan Tunggakan Pajak.
Tabel 5

ANOVA

\begin{tabular}{|c|c|c|c|c|c|c|}
\hline \multicolumn{2}{|c|}{ Model } & Sum of Squares & $d f$ & Mean Square & $\mathrm{F}$ & Sig. \\
\hline \multirow{6}{*}{1} & \multirow{2}{*}{ Regression } & 317000474512920 & 2 & 158500237256460 & 947 & .394 \\
\hline & & 7400000000 & & 3700000000 & & \\
\hline & \multirow{2}{*}{ Residual } & 95442995090111 & 57 & 167443851035282 & & \\
\hline & & 4000000.000 & & 7000000.000 & & \\
\hline & \multirow[t]{2}{*}{ Total } & 986129998352403 & 59 & & & \\
\hline & & 5000000.000 & & & & \\
\hline
\end{tabular}

a. Dependent Variable: pencairantunngagkan pajak

b. Predictors: (Constant), surtat paksa, suratteguran

Sumber: Data diolah menggunakan IBM SPSS 21

Berdasarkan tabel Anova diatas, nilai $\mathrm{F}$ yang diperoleh sebesar $0.947<$ 3.16 atau $\mathrm{F}$ Hitung $<\mathrm{F}$ Tabel, maka $\mathrm{Ho}_{4}$ diterima sehingga dapat diartikan Persamaan regresi linier berganda yang terbentuk tidak signifikan antara Surat Teguran dan Surat Paksa terhadap Pencairan Tunggakan Pajak.

\section{Tabel 6}

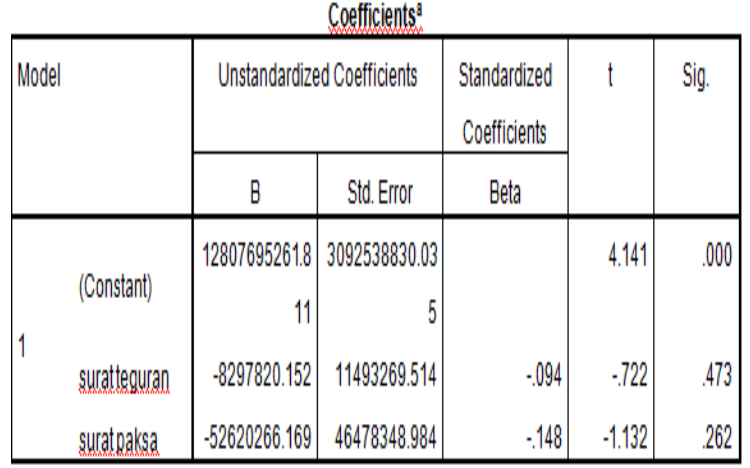

a. DependentVariable: pencairantungogakno paiak

Sumber: Data diolah menggunakan IBM SPSS 21

Berdasarkan hasil output dari tabel coefficients diatas, dapat diperoleh persamaan regresi linier berganda sebagai berikut:

$Y=12807695261.8-8297820.152 X_{1}-$ $52620266.169 \mathrm{X}_{2}$

Berdasarkan persamaan regresi berganda yang terbentuk dapat diartikan jika nilai variable $X_{1}$ (Surat Teguran) dan $\mathrm{X}_{2}$ (Surat Paksa) sama dengan nol maka 
nilai variable $\mathrm{Y}$ (Pencairan Tunggakan Pajak) 12807695261.8 atau $1.28 \%$.

\section{KESIMPULAN}

Berdasarkan penelitian yang telah dilakukan maka kesimpulan dalam penelitian ini adalah:

1. Secara korelasi parsial tidak terdapat hubungan yang signifikan antara surat teguran (X1) terhadap pencairan tunggakan pajak $(Y)$ dan antara surat paksa (X2) terhadap pencairan tunggakan (Y) sedangkan secara simultan tidak terdapat hubungan antara surat teguran dan surat paksa terhadap pencairan tunggkan pajak.

2. Secara simultan antara surat teguran dan surat paksa tidak mempengaruhi pencairan tunggakan pajak.

3. Persamaan regresi berganda yang terbentuk $Y=12807695261.8$ $8297820.152 X_{1}-52620266.169 X_{2}$ diartikan jika nilai variable $X_{1}$ (Surat Teguran) dan $X_{2}$ (Surat Paksa) sama dengan nol maka nilai variable $Y$ (Pencairan Tunggakan Pajak) 12807695261.8 atau $1.28 \%$.

\section{IMPLIKASI DAN KETERBATASAN}

Penelitian memiliki keterbatasan yang mempengaruhi hasil akhir dalam penelitian ini. Keterbatasan dalam penelitian ini dimana periode penelitian hanya 5 tahun yaitu 2013 sampai dengan 2017, pada variabel penelitian hanya variabel independen terdiri dari surat paksa dan surat teguran serta variabel dependen yaitu pencairan tunggakan pajak, diharapkan pada penelitian selanjutnya dapat menambah lebih banyak variabel independen dan menambah jumlah populasi dengan periode waktu penelitian yang lebih panjang dan dapat menambah variabel intervening dalam penelitian.

\section{Saran}

Berdasarkan kesimpulan yang telah dikemukakan diatas, maka diperoleh saran sebagai berikut:
1. Peneliti selanjutnya menambahkan variabel lain yang akan diuji dalam model penelitian, menambah jumlah populasi atau sampel, periode waktu penelitian yang lebih panjang sehingga mendapatkan hasil yang valid dan optimal.

2. Mengadakan sosialisasi kepada wajib pajak sebagai upaya dalam memberikan kesadaran wajib pajak untuk patuh membayar pajak tepat waktu.

3. KPP Madya Jakarta Utara dapat segera memperbarui master file alamat wajib pajak sehingga surat paksa dapat segera dikirim kealamat terbaru wajib pajak.

4. Menambah aparat pajak atau fiskus di KPP Madya Jakarta Utara sehingga penagihan pajak dapat lebih ditingkatkan baik melalui surat teguran maupun surat paksa dalam meningkatkan penerimaan pajak.

5. Dalam pelaksanaan penagihan pajak aparat pajak atau fiskus dapat lebih tegas dalam melakukan penagihan pajak terhadap wajib pajak yang tidak membayar pajak atau yang masih memiliki hutang pajak.

\section{REFERENCES}

Ayza, B. (2017). Hukum Pajak Indonesia. Jakarta: Kencana.

Fatmadika, D., Heru, S., \& Rosalita, R. A. (2016). Pengaruh Surat Teguran Terhadap Pencairan Tunggakan Pajak Dengan Surat Paksa Sebagai Variabel Interviening. Jurnal Perpajakan, 9(1), 1-8.

Fitrisyah, A., \& Ermadiani. (2014). Pengaruh Penagihan Pajak Dengan Surat Teguran Dan Surat Paksa Terhadap Penerimaan Tunggakan Pajak Badan Pada KPP Pratama Palembang Seberang Ulu. Jurnal Penelitian Dan Pengembangan Akuntansi, 8(1), 115-124. https://doi.org/10.26593/be.v18i2.11 87. 
Gani, I., \& Siti, A. (2015). Alat Analisi Data Aplikasi Statistik untuk Penelitian Bidang Ekonomi dan Sosial. Yogyakarta: CV Andi Offset.

Hidayat, N. (2013). Pemeriksaan Pajak. Jakarta: PT Elex Media Komputindo.

Lubis, I. (2011). Kreatif Gali Sumber Pajak Tanpa Bebani Rakyat. Jakarta: PT Elex Media Komputindo.

M.Farouq.S. (2018). Ukum Pajak Di Indonesia (Pertama). Jakarta: Kencana.

Nasution, H., \& Aliffoni, A. (2018). Analisis Efektivitas Penagihan Pajak dengan Surat Paksa dan Penyitaan untuk Meningkatkan Penerimaan Pajak pada Kantor Pelayanan Pajak Pratama Bekasi Utara, 13(1), 129 142.

Rantasari, R. W., Nur, H., \& M. Cholid Mawardi. (2019). Pengaruh Penagihan Pajak Dengan Surat Teguran Dan Surat Paksa Terhadap Penerimaan Pajak Pada Kantor Pelayanan Pajak Pratama Malang Utara. E-JRA, 08(2), 1-19.

Ratnawati, J., \& Retno Indah Hernawati. (2015). Dasar-Dasar Perpajakan (Pertama). Yogyakarta.

Sabrina, T., Siska, P. Y., \& Kurnia. (2018). Pengaruh Penagihan Pajak Aktif Dengan Surat Teguran Dan Surat Paksa Terhadap Efektivitas Pencairan Tunggakan Pajak. Assets Jurnal Ekonomi, Manajemen, dan Akuntansi, 8(1).

Soemarso. (2007). Perpajakan. Jakarta.

Supardi. (2013). Aplikasi Statistika Dalam Penelitian. Jakarta: Change Publication.

Syofian Siregar. (2017). Statistika Terapan Untuk Perguruan Tinggi (Pertama). Jakarta: PT Kharisma Putra Utama.
Undang-Undang Republik Indonesia Nomor 28 Tahun 2007 Tentang Perubahan Ketiga Atas UndangUndang Nomor 6 Tahun 1983 Tentang Ketentuan Umum Dan Tata Cara Perpajakan. (2007).

Wahdi, N., Ratna, W., \& Danang. (2018). Efektivitas Penagihan Pajak Dengan Surat Teguran, Surat Paksa, Dan Penyitaan Dan Kontribusinya Terhadap Penerimaan Pajak Di KPP Pratama Semarang Tengah Satu. Dinamika Sosial Budaya, 20(2), 106-119. 